\title{
The effect of different feeds, including those containing soya-bean products, on the passage of digesta from the abomasum of the preruminant calf
}

\author{
By R. H. SMITH AND J. W. SISSONS \\ National Institute for Research in Dairying, Shinfield, Reading $R G 2{ }_{9} A T$
}

(Received I8 March I974-Accepted I6 May I974)

\begin{abstract}
I. The effects of various factors on rates of flow and composition of digesta leaving the abomasum of preruminant calves were studied. The possible relation of some of these effects to the development of serum antibodies to certain dietary constituents has also been examined. Two situations were distinguished: $(a)$ unsensitized responses, shown by calves receiving milk protein or soya-bean products for the first one or two occasions; $(b)$ sensitized responses, shown by calves receiving certain soya-bean products, after a number of these feeds had been given.

2. For unsensitized calves, the rate of flow of total digesta from the abomasum was greater in the first few hours after a feed consisting of a mineral solution was given, than after cow's milk was given. This difference was apparently due to differences in the composition of digesta entering the duodenum. Total digesta flows after giving synthetic milk feeds, prepared from different protein sources, were similar to those after cow's milk was given.

3. For sensitized calves, rates of flow of total digesta from the abomasum were greatly affected by the nature of the protein source used in the diet. Soya-bean flour (heated or unheated) generally caused inhibition of flow for some hours after feeding; a soya-bean protein isolate (isoelectric) had a similar but smaller effect, but a soya-bean concentrate (prepared by alcohol extraction of a soya-bean flour) and milk protein had little or no effect. The inhibition, believed to be a sign of more general disorders, appeared to be caused by a factor entering the duodenum which induced a change in the way in which the calf responded, probably as the result of a gastrointestinal allergy.

4. Calves given soya-bean flour or a soya-bean protein isolate (isoelectric) in their diets for several weeks, showed respectively high and low titres of serum antibodies to an antigen prepared from soya-bean flour. Calves given alcohol-extracted soya-bean concentrate had no similar antibodies.

5. In addition to variations in total digesta flow, dietary nitrogen compounds were held up in the abomasum to different extents after different feeds. After a whole-milk feed or a synthetic feed prepared from casein, a slow, steady release of $\mathrm{N}$ occurred over at least $9 \mathrm{~h}$. $\mathrm{N}$ hold-up after giving soya-bean-containing feeds was slight for the soya-bean flour, but extremely marked for the soya-bean protein isolate (isoelectric). The latter hold-up was followed after several hours by a rapid outflow of $\mathrm{N}$ from the abomasum.
\end{abstract}

The movement of digesta from the abomasum of a calf given a feed of cow's milk is a slow, well-controlled process (Ash, 1964; Mylrea, I966a). The rate of flow of digesta is most rapid immediately after this type of feed and decreases progressively with time, although a considerable flow continues for many hours and remains appreciable even after an $\mathrm{I} 8 \mathrm{~h}$ fast. With increasing time the digesta contain greater proportions of materials of endogenous origin, but certain dietary constituents continue to be found for many hours. This applies particularly to nitrogenous components and fat, which are held back in the abomasum in a clot and are released, as the clot is digested, at a fairly constant rate for at least $7-9 \mathrm{~h}$ (Mylrea, $1966 b$; Toullec \& Mathieu, 1973). 
This ordered process may be upset in two main ways: (a) by inhibition or acceleration of movement of total digesta or $(b)$ by changes in clotting or other processes involved in the selective hold-up of individual constituents of the digesta. Such interference can greatly affect the flow of nutrients to the small intestine and it has been suggested that this may lead to a disturbance of the digestive processes (Tagari \& Roy, 1969).

Experiments with sheep and man (Phillipson, 1952; Hunt \& Knox, I971) have shown that digesta flow from the abomasum or the stomach is partly controlled by the amount and composition of digesta entering the duodenum. It has generally been assumed that a similar mechanism operates in the calf and, in experiments with this animal, collections of digesta from a duodenal cannula have usually been accompanied by the return of the digesta after measurement. However, the only direct observations on the factors influencing abomasal emptying in the calf are those of Tagari \& Roy (1969) on the effects of $\mathrm{pH}$ in duodenal digesta, and of Bell \& Razig (1973) on the rates of disappearance of test solutions added to a previously emptied calf abomasum.

In the present work we have studied some effects of modifying the amount and composition of digesta entering the duodenum on the rate of abomasal emptying. In other experiments we have taken care to ensure a smooth flow of digesta to the duodenum and have studied over-all digesta flow and the flows of nitrogen and a watersoluble marker from the abomasum after a variety of feeds, particularly feeds in which soya-bean products formed the main protein source. Soya-bean flour, suitably heated to destroy trypsin inhibitor and other deleterious factors, has been used in infant feeding (Vest, Olafson \& Schenker, I966) and although there have been some reports of ill effects (e.g. Ament \& Rubin, 1972) these are exceptional. Heated soya-bean flour has also been successfully used as the sole protein source for piglets older than 3 weeks (Coalson, Jones \& Lecce, 1972). It might be expected that this type of flour could be used to prepare milk substitutes for calf feeding. Attempts to give preruminant calves diets containing more than about $30-40 \%$ of their protein in the form of heated, fatextracted but otherwise untreated, soya-bean flour have, however, nearly always proved unsuccessful and have led to diarrhoea, weight loss or very poor growth, and sometimes death (Stein, Knodt \& Ross, 1954; Gorrill \& Thomas, 1967; Colvin \& Ramsey, 1968). Much of the work presented in this paper has been done to determine whether the patterns of digesta flow from the abomasums of calves given feeds containing heated soya-bean flour could be related to these over-all digestive disorders.

Certain aspects of our findings and those of van Adrichem $\&$ Frens (r965) and van Leeuwen, Weide \& Braas (1969) suggested that the disturbances may have been related to a gastrointestinal allergic reaction. Some studies of the development of circulatory antibodies to a constituent of soya-bean flour have, therefore, also been done.

Some of the findings have been briefly reported elsewhere (Smith, Hill \& Sissons, 1970; Smith \& Wynn, 1971). 


\section{METHODS}

\section{Flow of digesta from the duodenum}

Friesian bull calves (nos. I-II) were equipped with a re-entrant cannula in the duodenum less than $100 \mathrm{~mm}$ below the pyloric sphincter and above the bile duct. Cannulas were either moulded from flexible polyvinyl chloride, as described by Ash (I962), or machined from polyacetal (Kematal; ICI Plastics Division, Welwyn Garden City), as described by Coombe (1972). They were inserted when the calves were 2-6 weeks of age and the animals were also castrated at this time. All the calves except nos. $x-3$ were also provided with an abomasal cannula. This was made of polyacetal and consisted of an externally threaded tube $17 \mathrm{~mm}$ long, $12 \mathrm{~mm}$ internal diameter, I $7 \mathrm{~mm}$ external diameter, with a circular flange $50 \mathrm{~mm}$ in diameter $23 \mathrm{~mm}$ from the inner end. The cannula was installed with this flange against the inside of the abomasal wall and the outer end passed to the exterior just behind the ribs. It was held in position by a disc $45 \mathrm{~mm}$ in diameter screwed lightly against the outside of the body wall and was closed with a screw cap.

All the calves received colostrum up to $4 \mathrm{~d}$ of age and were then given whole milk by bucket, twice daily, in amounts calculated to give a growth rate of about $0.25 \mathrm{~kg} / \mathrm{d}$ (Roy, Shillam, Hawkins \& Lang, 1958). Daily supplements of $0.43 \mathrm{~g} \mathrm{FeCl}_{3} \cdot 6 \mathrm{H}_{2} \mathrm{O}$, $0.04 \mathrm{~g} \mathrm{MnSO}_{4} \cdot{ }_{4} \mathrm{H}_{2} \mathrm{O}, 0.04 \mathrm{~g} \mathrm{CuSO}_{4} \cdot{ }_{5} \mathrm{H}_{2} \mathrm{O}, 6 \mathrm{mg}$ retinol and $50 \mu \mathrm{g}$ cholecalciferol were given from 3 weeks of age. The calves were kept on this feeding regimen except when experimental feeds were given and the effects of different factors on digesta flow examined. These experimental collections of digesta were started no earlier than 2 weeks after the operation to install the cannulas and when the calves were $5^{-9}$ weeks of age. They were continued at intervals of 2-3 $\mathrm{d}$ for up to ro weeks.

Experimental feeds consisted of cow's milk or liquid synthetic feeds. The latter all contained (g/kg): $\mathrm{NaOH} 0 \cdot 85$, citric acid o.77, $\mathrm{Na}_{2} \mathrm{HPO}_{4} 0^{\circ} \cdot 42, \mathrm{~K}_{2} \mathrm{HPO}_{4} 2 \cdot 7 \mathrm{o}, \mathrm{KH}_{2} \mathrm{PO}_{4}$ $0.58, \mathrm{CaCl}_{2} \cdot 6 \mathrm{H}_{2} \mathrm{O} 2 \cdot 67, \mathrm{MgCl}_{2} \cdot 6 \mathrm{H}_{2} \mathrm{O} 0.94$. For some experiments no further additions were made; this feed will be referred to as the 'mineral-feed'. For other experiments, $14 \mathrm{~g}$ margarine (emulsified with $0.6 \mathrm{~g}$ Lubrol W (ICI Ltd)) and $32 \mathrm{~g}$ glucose were also included, together with a protein source consisting of $42 \mathrm{~g}$ calcium caseinate, or one of the soya-bean products shown in Table I. Amounts $(\mathrm{g} / \mathrm{kg})$ of the soya-bean products added were: soya-bean protein isolates, products $F$ or $G 44$; soya-bean concentrates, products $\mathrm{D}$ or $\mathrm{E} 52$; soya-bean flours, products $\mathrm{A}, \mathrm{B}$ or $\mathrm{C} 66$. These feeds will subsequently be identified simply by their protein source (e.g. casein-feed or product A-feed). Occasional experiments were also done using feeds from which one or two of the dietary components, margarine, glucose or calcium caseinate were omitted. All feeds contained $5 \mathrm{~g}$ polyethylene glycol (molecular weight 4000) (PEG) as a marker. In later experiments a tracer dose $(2 \cdot 5 \mu \mathrm{Ci})$ of [U-14 $\mathrm{C}] \mathrm{PEG}$ (NEN Chemicals GmbH, Dreieichenhain, West Germany) was also included. Feeds were given at an average rate of $5 \circ \mathrm{g} / \mathrm{kg}$ body-weight but absolute amounts were kept constant for any one group of collections for a single calf in which different feeds were compared. Intakes therefore varied between 40 and $60 \mathrm{~g} / \mathrm{kg}$ body-weight.

Experiments were of three kinds. 
Table r. Outline of procedures used for preparing the different soya-bean products given to calves

Fat-extracted, dehulled soya-bean meal

Solvent removed with only light heating

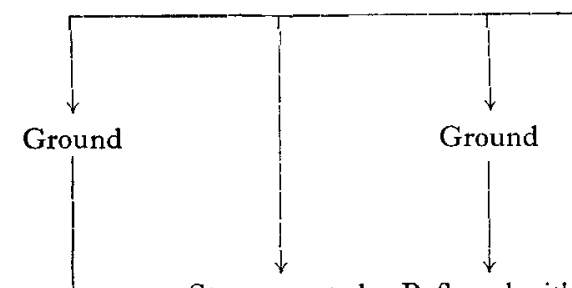

Steam-treated, Refluxed with ground aqueous ethanol

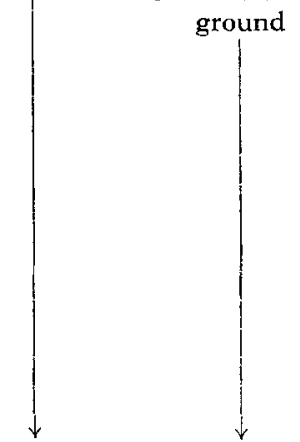

Soya-bean flour

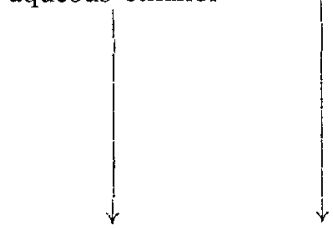

Steam-heated

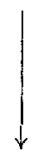

Residue steamheated and ground

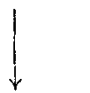

Soya-bean concentrate

$\overbrace{}^{\text {Soya-bean concentrate }}$

Lightly heated

Heated

Ethanol-treated

B C

$55^{\circ}$

D

E

680

$5-7$

$4 \cdot 9-9 \cdot 6$

I6-2I

5

$38-50$
$27-35$

$6 \cdot 9-8 \cdot 0$

$6 \cdot 5$

680

(1)

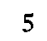

$3 \cdot 2$

$3 \cdot 2$

$I-2$

56

(units $\uparrow / g$ )

Steam treatment for product $\mathrm{C}$ was at $100^{\circ}$ for $30 \mathrm{~min}$ and for products $\mathrm{B}, \mathrm{D}$ and $\mathrm{E}$ was industrial, but under the same conditions. Ail products were ground to roo-200 mesh.

NSI, nitrogen solubility index (American Oil Chemists' Society, 1965).

* Products A, B and E (Mellasoy $Y_{30}$ and YIO, and 'Swifts' food protein' respectively) were supplied by Swift \& Co., Chicago, Ill., USA; product D (Promosoy roo or Haypro-T) was supplied by Central Soya, Chicago, Ill., USA or Hayes (Ashdod) Ltd, Israel, respectively (these two brands behaved similarly in our experiments and were not further distinguished); product G (Promine-D) was supplied by Central Soya; product F (Assay Protein $\mathrm{C}_{1}$ ) was supplied by Skidmore Enterprises, Cincinnati, Ohio, USA; product $\mathrm{C}$ was prepared in the laboratory by heating product $\mathrm{A}(\mathrm{I} 73 \mathrm{~g})$ with $255 \mathrm{ml}$ ethanol and $85 \mathrm{ml}$ water at $60^{\circ}$ under reflux with agitation for $2 \mathrm{~h}$ and then evaporating to dryness under reduced pressure.

$\uparrow$ For definition of units, see Kakade, Rackis, McGhee \& Puski (1974). 
Expt $\mathrm{I}$. Comparisons of digesta flow for different feeds containing milk protein, no protein or a soya-bean protein source when a soya-bean product had not previously been given on more than one occasion

In any one set of trials comparisons were made between up to four different experimental feeds. These feeds were given successively at intervals of $2-3 \mathrm{~d}$ and the group of comparisons then repeated at least once. A casein-feed was included for every group examined, to provide a reference standard.

For each experimental collection a calf was placed into a restraining crate at 08.30 hours, having been previously acclimatized to this restraint, and its re-entrant cannula was opened. At 09.00 hours it was given an appropriate experimental feed. For a period of 6-9 h samples of digesta flowing out of the proximal cannula were weighed, warmed to $39^{\circ}$ and returned to the distal cannula. Preliminary experiments showed that if the weights of these samples exceeded about I00-I $50 \mathrm{~g}$ then digesta left the abomasum in successive periods of fast and slow flow. For the trials reported, samples of 50-70 $\mathrm{g}$ were collected and rapidly returned; flow was then essentially smooth. For the trials with calf no. I, collection, measurement and return were done manually; for calf nos. 2-I I, these operations were automated and digesta leaving a proximal cannula were pumped to a jacketed vessel, kept at $39^{\circ}$, and then pumped back to the distal cannula. Automatic measurement of flow was made after previous calibration either by recording the number of times that a vessel (capacity about $50 \mathrm{~g}$ ) automatically filled and emptied or by means of a metering pump. About 10\% of the digesta flow was removed for analysis and replaced by an equal volume of a solution $(0.28 \mathrm{M}-$ glucose, $0.12 \mathrm{M}-\mathrm{NaCl}, 0.02 \mathrm{M}-\mathrm{HCl}$ ) shown to have an effect on abomasal emptying rate similar to that of abomasal digesta (see solution $\mathrm{A}$, Table 4).

Because the calves often refused to drink some of the synthetic feeds all experimental feeds, except those for calf nos. 1,2 and 3 which were given orally, were given by infusion into the abomasum. The feed was allowed to enter the abomasum at a rate $(300 \mathrm{ml} / \mathrm{min})$ no greater than the average drinking rate of a calf. Feeding in this way is likely to lead to a reduction of lipolysis in the abomasum as a result of lower concentrations of pregastric esterase (Siewert \& Otterby, I968) but it was shown in preliminary experiments that there were no marked differences in digesta $\mathrm{pH}$, or in the rates of flow of total digesta, dry matter or total $\mathrm{N}$ from the abomasum when comparing feeding by mouth with feeding by abomasal infusion.

\section{Expt 2. Changes in flow of digesta as a result of giving a number of successive feeds containing soya-bean products}

Experimental details for feeding the calves and making digesta collections were similar to those described for Expt I but comparisons were made between at least five trials done at intervals of $2-8 \mathrm{~d}$ in which feeds containing a soya-bean protein source (product B) were given. Casein-feeds, to act as a standard reference, were also given at intervals of not more than $14 \mathrm{~d}$. After at least four product $\mathrm{B}$-feeds had been given, when changes in abomasal emptying rate had become apparent, comparisons 
between product B-feeds, casein-feeds and feeds prepared from other soya-bean protein sources were sometimes done.

\section{Expt 3. Effect of the composition of digesta entering the duodenum on the rate of abomasal emptying}

In these trials the calves were fed in a similar way to those in Expt $\mathrm{r}$ and 2, but the whole of the digesta leaving a proximal cannula was collected and other materials were returned to the distal cannula at the same rate as the outflow of digesta.

The 'return' materials used in these trials consisted either of an acidified solution containing $\mathrm{NaCl}$ and glucose (solution $\mathrm{A}$, see Table 4) or digesta samples collected on a previous occasion from the same calf.

\section{Production of circulating antibodies}

Friesian bull calves (nos. 12-20) were used. With one exception (calf no. 12) the calves at first received colostrum and whole milk as described for fistulated calves and then, from 4 to 7 weeks of age, they were given $80-90 \mathrm{~g} / \mathrm{kg}$ body-weight per $\mathrm{d}$ of one of the following experimental diets, which contained $(\mathrm{g} / \mathrm{kg})$ : water 250 , cow's milk 720 , glucose $10, \mathrm{NaOH} 0.29$, citric acid $0.26, \mathrm{MgCl}_{2} \cdot 6 \mathrm{H}_{2} \mathrm{O} 0.24$; with the following supplements: soya-bean flour, product $B 20$ or soya-bean concentrate, product D I 6 or soya-bean protein isolate, product $F$ I2. Calf no. I 2 received colostrum, to which $25 \mathrm{~g}$ product $\mathrm{B} / \mathrm{kg}$ had been added, from birth to $4 \mathrm{~d}$ of age when the diet containing product $\mathrm{B}$ was given.

Samples of jugular blood were taken from these animals before, and at about weekly intervals after, the experimental diets were introduced. Similar blood samples were sometimes taken from the fistulated calves. Samples were kept at $37^{\circ}$ until they had clotted (about $0.5 \mathrm{~h}$ ). The serum was separated, incubated at $56^{\circ}$ for $0.5 \mathrm{~h}$ to destroy complement and examined, either immediately, or after storage at $-20^{\circ}$, for the presence of circulating antibodies to an antigen present in a digest prepared in vitro by pepsin and trypsin treatment of heated, fat-extracted soya-bean flour (product B). This digest was prepared in the same way as a digest prepared from wheat gluten, and referred to as 'fraction 3 ' by Frazer, Fletcher, Ross, Shaw, Sammons \& Schneider (1959). The product was freeze-dried.

Measurements of antibody titre in the serum samples were done using a haemagglutination method based on that of Boyden (I95 I). Sheep erythrocytes were separated by centrifugation from Alsever's solution (Wellcome Reagents Ltd, Beckenham BR3 $\left.{ }_{3} \mathrm{BS}\right)$ and were washed three times with buffered saline $(0.137 \mathrm{M}-\mathrm{NaCl}, 0.069 \mathrm{M}-$ $\mathrm{K}_{2} \mathrm{HPO}_{4}, 0.0025 \mathrm{M}-\mathrm{KH}_{2} \mathrm{PO}_{4} ; \mathrm{pH} 7 \cdot 2$ ). Two I $\mathrm{ml}$ samples of the packed cells were each added to $20 \mathrm{ml}$ buffered saline containing $0.5 \mathrm{mg}$ tannic acid (BDH Chemicals Ltd, Poole BHr2 4 NN) and the mixtures incubated at $37^{\circ}$ for $0.5 \mathrm{~h}$. The cells were separated by centrifugation and were washed once with buffered saline. One of the samples was mixed with $20 \mathrm{ml}$ buffered saline (A) and the other with $20 \mathrm{ml}$ buffered saline containing $0.05 \mathrm{~g}$ freeze-dried, soya-bean-flour digest (B), and each was incubated at $37^{\circ}$ for $0.5 \mathrm{~h}$. The cells were separated by centrifugation, washed three times 
with an aqueous solution of inactivated rabbit serum (Wellcome Reagents Ltd, Beckenham $\left.\mathrm{BR}_{3}{ }_{3} \mathrm{BS}\right)(\mathrm{r} \circ \mathrm{g} / \mathrm{l})$ and suspended in $50 \mathrm{ml}$ of this solution. A sample $(0.5 \mathrm{ml})$ of the calf serum to be tested was added to $4.5 \mathrm{ml}$ of the suspension obtained from $\mathrm{A}$, allowed to stand for $\mathrm{romin}$, and the cells were removed by centrifugation. A sample $(0.2 \mathrm{ml})$ of the supernatant fraction was added to the first of a series of test-tubes. Successive tubes contained $0.2 \mathrm{ml}$ samples of mixtures prepared by 2 -fold serial dilutions of the supernatant fraction with an aqueous solution of rabbit serum ( $1 \circ \mathrm{g} / 1)$. Samples $(0.2 \mathrm{ml})$ of the suspension obtained from B were added to each tube. The tubes were shaken and then allowed to stand at about $4^{\circ}$ for $16 \mathrm{~h}$. The series of tubes were prepared in duplicate, together with a further series of tubes prepared using suspension A as a control. The antibody titre was measured as the greatest dilution which was found to have a sediment formation characteristic of agglutinated cells.

\section{Analytical methods}

Total N. Samples of homogenized digesta (I g), liquid feed (I g) or dietary protein source $(0.1 \mathrm{~g})$ were digested with $3 \mathrm{ml}$ sulphuric acid-potassium sulphate-mercuric oxide (Fleck \& Munro, I965). Hydrogen peroxide solution (approximately $8.9 \mathrm{~mol} / \mathrm{l}$ ) was occasionally added dropwise to facilitate digestion of some samples. Solutions were made up to contain $0.020-0.140 \mathrm{~g}$ ammonia $\mathrm{N} / \mathrm{l}$. The ammonia $\mathrm{N}$ content was estimated colorimetrically (Technicon Instruments Ltd, 1967) using an AutoAnalyzer (Technicon Instruments Ltd, Basingstoke, Hants).

$N$ soluble in trichloroacetic acid (TCA-soluble $N)$. A sample of homogenized digesta was added to an equivalent weight of trichloroacetic acid (TCA) solution $(200 \mathrm{~g} / \mathrm{l})$. The mixture was kept at $4^{\circ}$ for $16 \mathrm{~h}$ and filtered.

$P E G$. The amount of unlabelled PEG in digesta samples was determined by the method described by Smith $\left(195^{8}, 1962\right)$ except that 20 min was allowed for the development of turbidity. The amount of $\left[\mathrm{U}-{ }^{14} \mathrm{C}\right] \mathrm{PEG}$ was determined by the method of Coombe \& Smith (1973).

Solubility of nitrogenous components of soya-bean protein sources. This was determined as the ' $\mathrm{N}$ solubility index' (NSI) as described by the American Oil Chemists' Society ( 1965$)$.

Trypsin inhibitor in soya-bean protein sources. The trypsin inhibitor content was determined, and results expressed, as trypsin inhibitor units by the method of Kakade, Rackis, McGhee \& Puski (1974).

\section{RESULTS}

Flow of digesta from the abomasum into the duodenum

For calves given whole milk or synthetic feeds containing casein as the sole protein source, there were no consistent changes in the patterns of flow of total digesta, watersoluble marker or nitrogenous constituents from the abomasum as the number of times that the diet was given was increased. Also, there were no appreciable differences, within the ranges of conditions studied, associated with the age of the calves. This is shown for total digesta flow in Table 2. When more than two feeds containing certain soya-bean products were given, however, the patterns of flow from the abomasum 
Table 2. Effect of age and successive experimental feeds on the flow of digesta

$$
\text { from the calf abomasum }
$$

(Mean values with their standard errors are given for the groups of calves. Individual calf values on which these means were based were themselves the means of two to five values)

\begin{tabular}{|c|c|c|c|c|c|c|}
\hline \multirow{3}{*}{$\begin{array}{l}\text { No. of } \\
\text { calves }\end{array}$} & \multirow[b]{3}{*}{ Experimental feed } & \multirow{3}{*}{$\begin{array}{l}\text { Age } \\
\text { (d) }\end{array}$} & \multicolumn{4}{|c|}{ Total digesta flow ( $\mathrm{g} / \mathrm{kg}$ feed) } \\
\hline & & & \multicolumn{2}{|c|}{$\begin{array}{c}\begin{array}{c}0 \cdot 5-2 \cdot 0 \mathrm{~h} \text { after } \\
\text { feeding }\end{array} \\
\end{array}$} & \multicolumn{2}{|c|}{$\begin{array}{l}0.5-3.5 \mathrm{~h} \text { after } \\
\text { feeding }\end{array}$} \\
\hline & & & Mean & $\mathrm{SE}$ & Mean & SE \\
\hline 5 & $\begin{array}{r}\text { 'Casein' rst or } 2 \text { nd } \\
\text { Ist or } 2 \text { nd }\end{array}$ & $\begin{array}{l}30-50 \\
70-100\end{array}$ & $\begin{array}{l}280 \\
280\end{array}$ & $\begin{array}{l}30 \\
30\end{array}$ & $\begin{array}{l}570 \\
520\end{array}$ & $\begin{array}{l}70 \\
30\end{array}$ \\
\hline 3 & $\begin{array}{r}\text { Whole milk ist or 2nd } \\
\text { Ist or } 2 \text { nd }\end{array}$ & $\begin{array}{l}30-50 \\
70-100\end{array}$ & $\begin{array}{l}330 \\
290\end{array}$ & $\begin{array}{l}30 \\
20\end{array}$ & $\begin{array}{l}580 \\
610\end{array}$ & $\begin{array}{l}60 \\
20\end{array}$ \\
\hline 4 & $\begin{array}{r}\text { 'Casein' rst or } 2 \text { nd } \\
4 \text { th to } 8 \text { th }\end{array}$ & $3^{\circ}-150$ & $\begin{array}{l}280 \\
330\end{array}$ & $\begin{array}{l}10 \\
60\end{array}$ & $\begin{array}{l}520 \\
600\end{array}$ & $\begin{array}{l}10 \\
60\end{array}$ \\
\hline 3 & $\begin{array}{r}\text { Whole milk ist or } 2 \text { nd } \\
4^{\text {th }} \text { to } 8 \text { th }\end{array}$ & $60-I_{50}$ & $\begin{array}{l}220 \\
270\end{array}$ & $\begin{array}{l}30 \\
60\end{array}$ & $\begin{array}{l}550 \\
620\end{array}$ & $\begin{array}{l}50 \\
80\end{array}$ \\
\hline
\end{tabular}
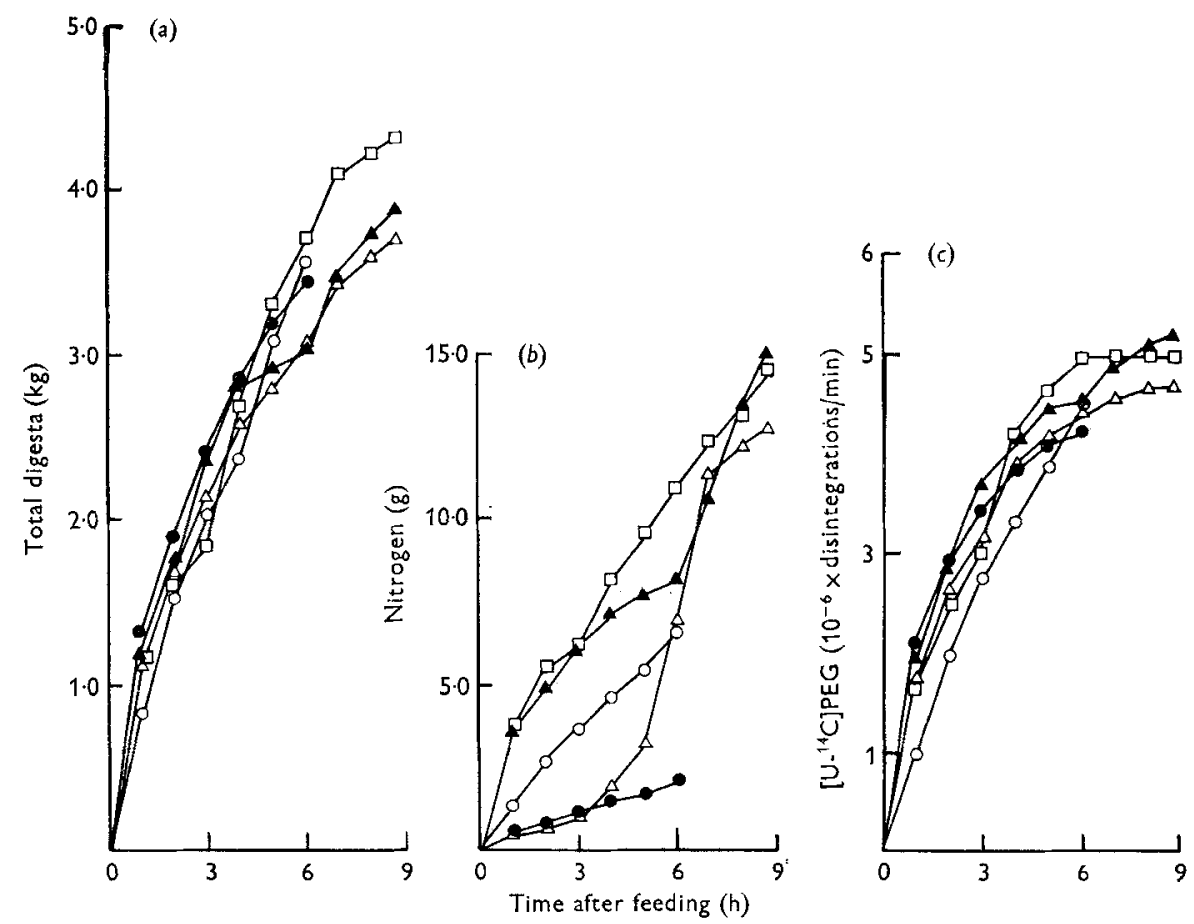

Fig. I. Cumulative amounts of $(a)$ total digesta, $(b)$ nitrogen and $(c)$ [U- $\left.{ }^{14} \mathrm{C}\right]$ polyethylene glycol (PEG) entering the proximal duodenum of an unsensitized calf after receiving approximately $3 \mathrm{~kg}$ whole milk (O), mineral-feed (liquid synthetic feed containing no casein, fat or glucose) (O), or synthetic feeds prepared from product B (heated soya-bean flour) $(\boldsymbol{A})$, product $F$ (soya-bean protein isolate (isoelectric)) $(\triangle)$ or casein $(\square)$. All feeds contained [U- $\left.{ }^{14} \mathrm{C}\right] \mathrm{PEG}\left(4^{\cdot 8-5.2} \times 10^{6}\right.$ disintegrations $\left./ \mathrm{min}\right)$. For details of feed composition see p. $33^{\mathrm{I}}$ and Table $\mathbf{I}$. 


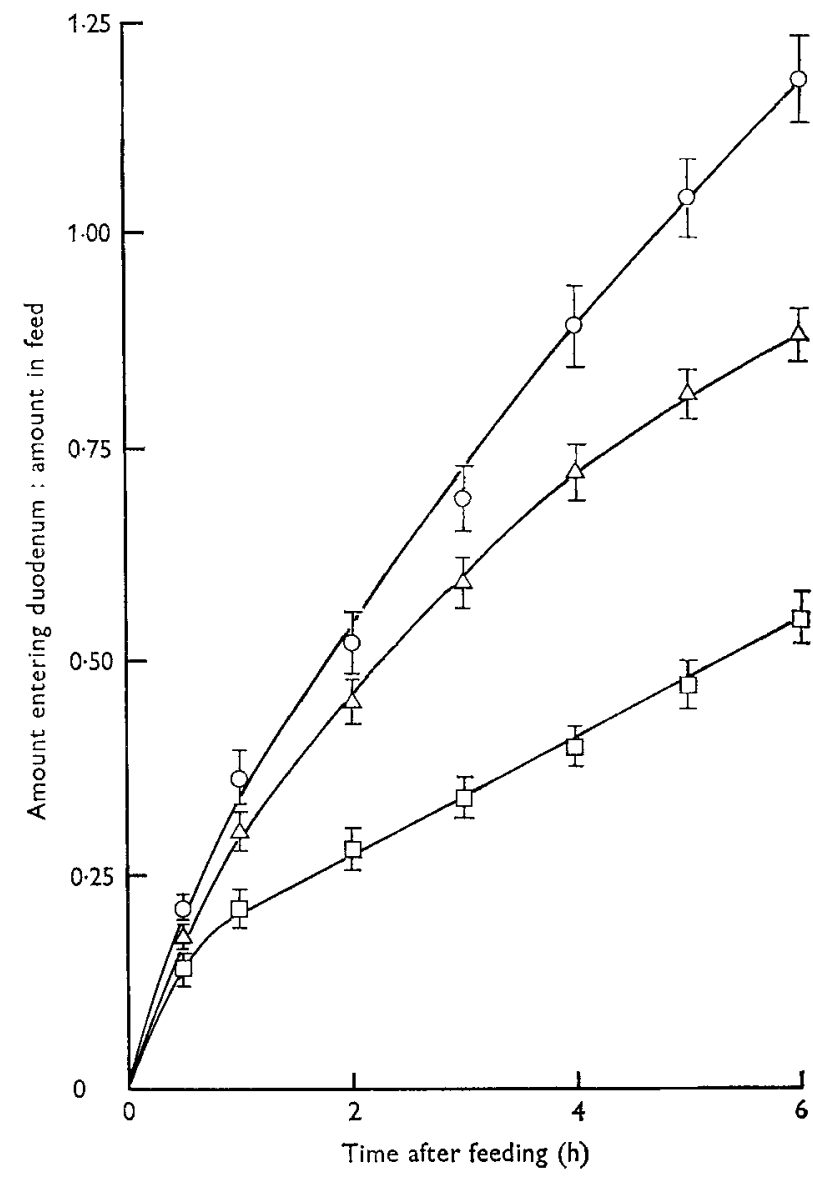

Fig. 2. Cumulative amounts of total digesta $(O)$, PEG $(\triangle)$ and nitrogen $(\square)$ entering the proximal duodenum of unsensitized calves at different times after receiving casein-feeds (liquid synthetic feed containing casein as its protein source, for details, see p. 33 I). Amounts are expressed as proportions of the amounts ingested and are given as mean values, with their standard errors represented by vertical bars, for eleven calves. Values for the individual calves used to derive these means were themselves the means of two to six values for each calf.

after these feeds usually changed markedly. This finding will be considered in more detail later but it is suggested (Smith \& Wynn, 1971) that these changes are the result of the development of a gastrointestinal allergy and that the initial feeds sensitized the calf to a constituent in the soya-bean product. Expt I was, therefore, designed to show the effect of diet on the flow of digesta from the abomasum to the duodenum for unsensitized calves and Expt 2 showed the effects of sensitization to these products.

Expt $\mathrm{x}$. Results given in Fig. I are for individual experiments with a single calf. They show marked differences in $\mathrm{N}$ flows between some of the feeds but no obvious differences in total digesta or water-soluble marker. Repeated observations with this calf and other calves generally confirmed the differences for $\mathrm{N}$ flows and also indicated some consistent differences for total digesta and PEG flows. Concise representation of these effects is difficult because, for any one feed, there were appreciable differences in 


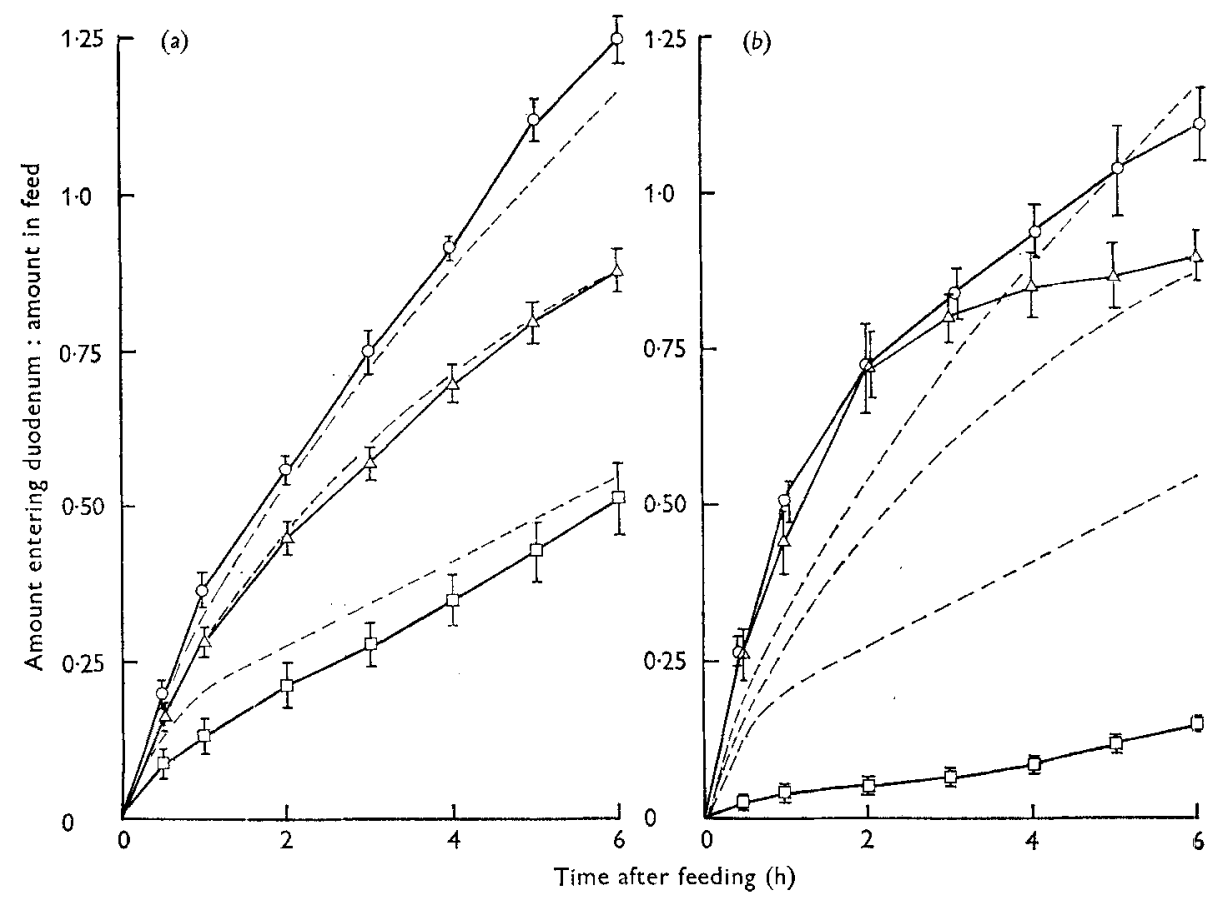

Fig. 3. Cumulative amounts of total digesta $(O)$, polyethylene glycol $(\triangle)$ and nitrogen $(\square)$ entering the proximal duodenum of unsensitized calves at different times after receiving $(a)$ whole milk (nine values, seven calves) and $(b)$ mineral-feed (liquid synthetic feed containing no casein, fat or glucose) (five values, three calves). Amounts are expressed as proportions of the amounts ingested (except that amounts of $\mathrm{N}$ for the mineral-feed are expressed as proportions of the $\mathrm{N}$ ingested with a casein-feed (liquid synthetic feed with casein as its protein source)) and given as mean values; with their standard errors represented by vertical bars. All values were adjusted to relate them to over-all mean values for the casein-feed (see p. 338). These values (---) (from Fig. 2) were used as common reference values. For details of feeds, see p. $33 \mathrm{I}$ and Table I.

absolute flow characteristics between calves. This is shown for calves given the caseinfeed in Fig. 2. Although there were absolute differences, the relationships between flows for different diets remained fairly constant between animals. Variability between calves in this respect was no greater than that between replicate comparisons for the same animal. Each value for a particular diet, therefore, was expressed as a proportion of the corresponding value for a casein-feed obtained with the same calf within the same trial, over a period of not more than 3 weeks. From these proportions, curves for each diet corresponding to the mean curves for the casein-feed, shown in Fig. 2, were calculated. This method has been used in calculating the results shown in Figs. 3 and 4 .

The results in Fig. 3 suggested that patterns of digesta flow after a calf had received whole-milk feed were generally similar to those obtained after giving a casein-feed. The only appreciable difference was that, after the latter, a significantly $(P<0.0 \mathrm{I})$ greater amount of $\mathrm{N}$ was recovered at the duodenum in the Ist hour after feeding. When casein, fat and glucose were omitted from the synthetic feed (mineral-feed), the flow of total digesta and PEG was significantly $(P<0.05)$ more rapid in the first 


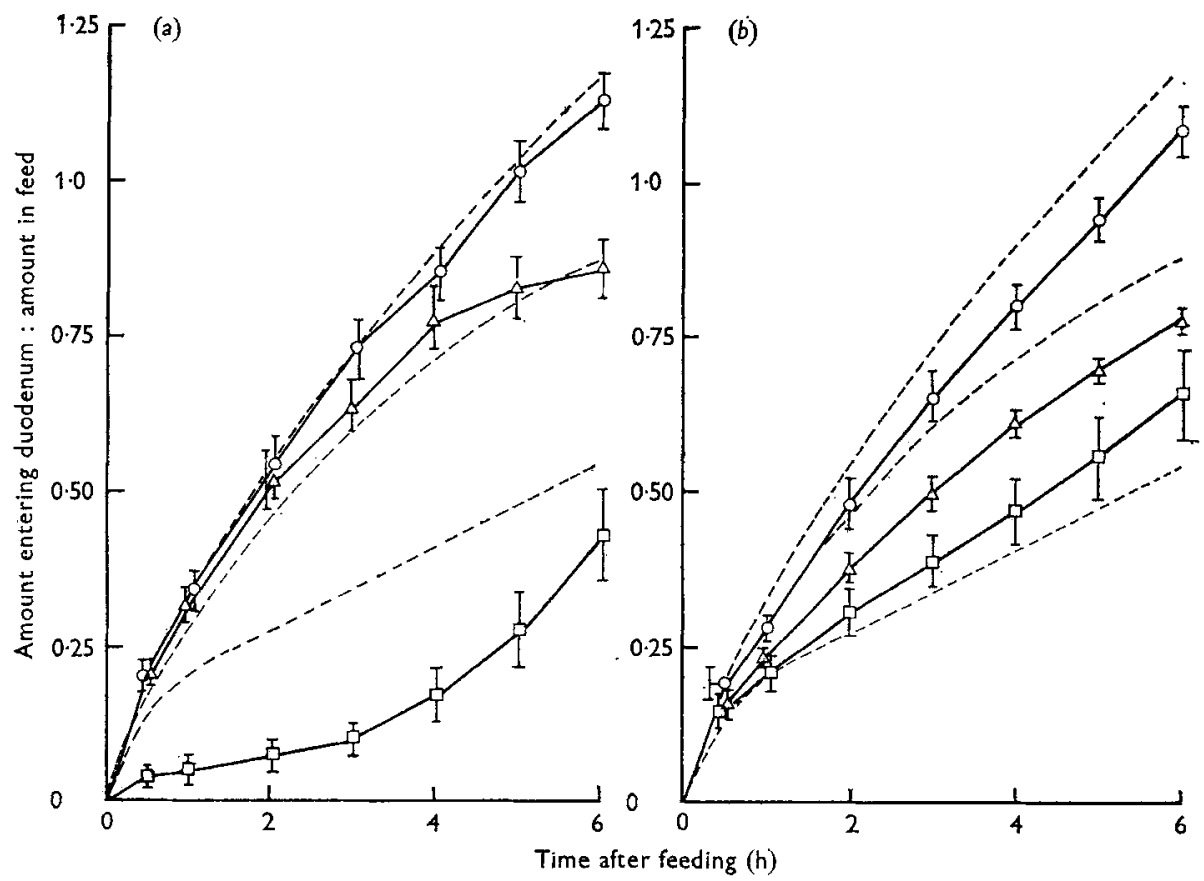

Fig. 4. Cumulative amounts of total digesta (O), polyethylene glycol $(\triangle)$ and nitrogen ( $\square$ ) entering the proximal duodenum of unsensitized calves at different times after receiving (a) product $\mathbf{F}$ (soya-bean protein isolate (isoelectric))-feed (eight values, four calves) and $(b)$ product $B$ (heated soya-bean flour)-feed (thirteen values, seven calves). Amounts are expressed as proportions of the amounts ingested and given as mean values, with standard errors represented by vertical bars. All values were adjusted to relate them to over-all mean values for the casein-feed (see p. 338). These values (----) (from Fig. 2) were used as common reference values. For details of feeds, see p. $33 \mathrm{I}$ and Table $\mathrm{I}$.

$2 \mathrm{~h}$ after feeding, but was then slower, so that by $6 \mathrm{~h}$ after feeding, cumulative flow was about the same for the casein- and mineral-feeds. For two calves similar experiments were done in which, apart from minerals, casein only (five trials), casein + glucose (two trials), fat only (three trials) or casein + fat (three trials) were added to the feeds. Total flow characteristics intermediate between those shown for the mineraland casein-feeds were found. For all feeds in which casein was present, the flow of N was closely similar to that obtained for the casein-feed (Fig. 2). For all N-free feeds it was similar to that obtained for the mineral-feed (Fig. 3 ) and presumably represented endogenous secretion.

The results shown in Fig. 4 suggested that there were only small differences in total digesta or PEG flow into the duodenum of unsensitized calves given different dietary protein sources. There were, however, very marked differences in $\mathrm{N}$ flow between the diets. There was, as might have been expected, a more rapid flow of $\mathrm{N}$ from the abomasum after giving product $B$ (heated soya-bean flour)-feeds than after giving feeds containing milk protein. However, when compared to PEG, even the soya-bean-flour $\mathrm{N}$ was held up in the abomasum. A similar $\mathrm{N}$ flow was found also in trials in which product A (unheated soya-bean flour) was used. Surprisingly, there 


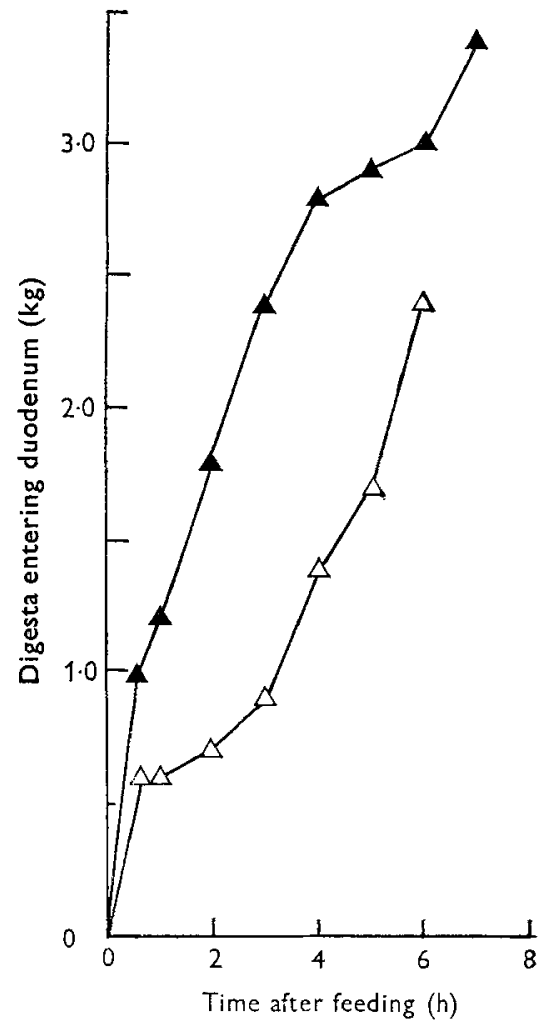

Fig. 5. Cumulative amounts of digesta entering the proximal duodenum of a calf at different times after receiving $3 \mathrm{~kg}$ product $\mathrm{B}$ (heated soya-bean flour)-feed for the Ist time (unsensitized) $(\Delta)$ and $5^{\text {th }}$ time (sensitized) $(\triangle)$. For details of feed, see p. 33 I and Table I.

was a much more severe hold-up of $\mathrm{N}$ for approximately $4-5 \mathrm{~h}$ after product $\mathrm{F}$ (soyabean-protein isolate (isoelectric))-feeds were given. The hold-up was followed by a period of rapid $\mathrm{N}$ flow. This finding is shown in Fig. I for an individual trial and in Fig. 4 as a mean effect. This type of hold-up was not found in two trials with one calf in which a product $\mathrm{G}$ (soya-bean protein isolate (Na proteinate))-feed was given.

Expt 2. The results given in Fig. 5 for an individual calf show a marked difference between the pattern of flow of digesta into the duodenum when the calf was given a product $\mathrm{B}$-feed for the Ist time and the corresponding pattern when it was given this feed for the $5^{\text {th }}$ time. With the $5^{\text {th }}$ feed there was, in particular, a marked retention of digesta in the abomasum for several hours after feeding. To express and compare the extent of such retentions in calves given a number of product B-feeds the amounts of digesta which flowed between $0.5-2 \cdot 0 \mathrm{~h}$ and $0.5-3.5 \mathrm{~h}$ after a feed were measured and expressed as proportions of the corresponding digesta flows after a casein-feed was given to the same calf within $20 \mathrm{~d}$. Mean values, which are given in Table 3, showed that there was a marked increase in abomasal retention after three or four product B-feeds had been given. Individually all the calves examined except one (calf no. 3 , which remained apparently unaffected) showed similar changes on becoming sensitized but to differing extents. As examples, calf nos. 6, I I and 9, given product 
Table 3. Cumulative amounts of digesta entering the proximal duodenums of calves given a series of product $B$ (heated soya-bean flour)-feeds*, as proportions of the corresponding values for casein-feeds*

(Mean values with their standard errors; no. of calves in parentheses)

\begin{tabular}{|c|c|c|c|c|}
\hline \multirow{3}{*}{$\begin{array}{l}\text { Time after feeding (h) ... } \\
\text { Product B-feed }\end{array}$} & \multicolumn{4}{|c|}{$\begin{array}{c}\text { Digesta flow after product B-feed: digesta flow } \\
\text { after casein-feed }\end{array}$} \\
\hline & \multicolumn{2}{|c|}{$0.5-2.0$} & \multicolumn{2}{|c|}{$0.5-3.5$} \\
\hline & Mean & $\mathrm{SE}$ & Mean & SE \\
\hline rst & 0.74 & $0.06(6)$ & $0.8 \mathrm{I}$ & $0.05(6)$ \\
\hline and & 0.89 & 0.1 I (6) & 0.97 & $0.09(6)$ \\
\hline 3 rd & 0.64 & $0.14(5)$ & 0.74 & $0.16(5)$ \\
\hline $4^{\text {th }}$ & 0.50 & O.I 5 (4) & 0.60 & $0.14(4)$ \\
\hline $5^{\text {th }}$ & 0.42 & $0.07(5)$ & 0.69 & $0.08(5)$ \\
\hline 6th & 0.60 & $0.07(5)$ & 0.77 & $0.04(5)$ \\
\hline $7^{\text {th }}$ & 0.42 & 0.04 (5) & 0.70 & $0.05(5)$ \\
\hline 8 th & 0.46 & $0.14(3)$ & 0.63 & $0.01(2)$ \\
\hline
\end{tabular}

$\mathrm{B}$-feeds after sensitizing, had digesta flows between 0.5 and $2 \cdot 0 \mathrm{~h}$ after feeding (relative to those for casein-feeds) of $0.68 \pm 0.09(6), 0.49 \pm 0.06(8)$ and $0.18 \pm 0.05$ (3) respectively (mean and SE, no. of trials in parentheses). The effects of giving feeds containing other soya-bean products, compared to those for product B- or casein-feeds, were studied using some of the sensitized calves. Feeds prepared from product A (four calves), product $E$ (three calves) or product $G$ (one calf) caused retention in the abomasum similar to that caused by product B-feeds. On the other hand, compared to casein-feeds, those prepared from product $C$ (two calves) and product $D$ (two calves) showed little or no hold-up. For product F-feeds (two calves) the hold-up in the abomasum was small and intermediate between the two extremes.

An inhibition of total digesta flow from the abomasum, in this experiment, was accompanied by a corresponding inhibition in the flows of PEG and N. Typical results, shown in Fig. 6, suggested that the flow of $\mathrm{N}$ was also affected by selective hold-up in a manner similar to that described for unsensitized calves (see Fig. 4).

Expt 3. In experiments reported so far, the digesta collected from the proximal duodenal cannula were mostly returned to the duodenum after measurement. It was not clear whether differences in abomasal emptying found for different feeds were mediated by effects in the abomasum or in the duodenum. This was studied in trials in which digesta samples from a proximal cannula were not returned to the duodenum but were sometimes replaced by matched amounts of an acidified solution containing $\mathrm{NaCl}$ and glucose (solution $\mathrm{A}$ ) or digesta samples collected on previous occasions. Results, expressed as effects on the amounts of digesta collected between 0.5 and $2 \cdot 0 \mathrm{~h}$ after feeding are given in Table 4 for both unsensitized and sensitized calves.

The infusion of solution $A$ into the duodenum of calf nos. I and 2 led to rates of flow of digesta from their abomasums which did not differ greatly from those found when digesta from whole-milk feeds were returned to the duodenum; in one calf the 


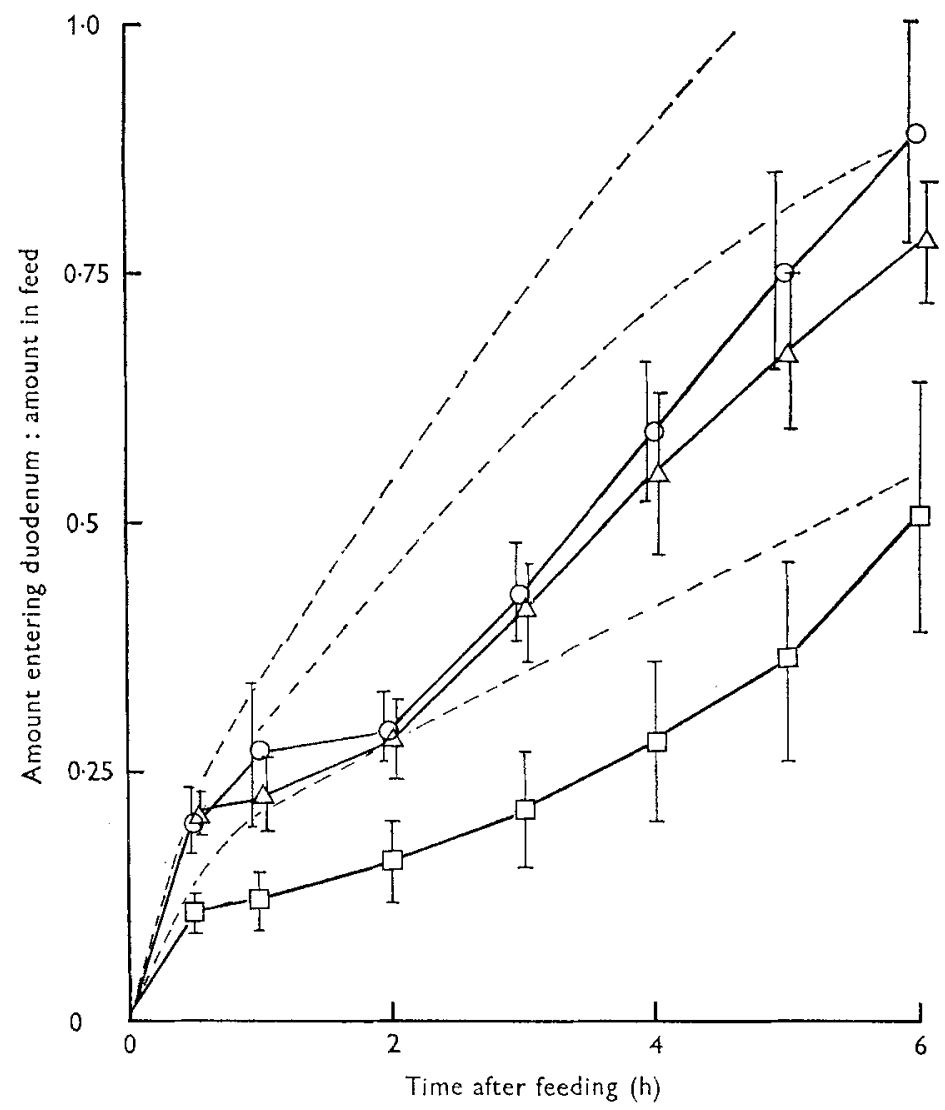

Fig. 6. Cumulative amounts of total digesta (O), polyethylene glycol $(\triangle)$ and nitrogen $(\square)$ entering the proximal duodenums of four sensitized calves given product $B$ (heated soya-bean flour)-feeds for the 5 th time. Amounts are expressed as proportions of the amounts ingested and given as mean values, with their standard errors represented by vertical bars. All values were adjusted to relate them to over-all mean values for the casein-feed (see p. 338). These values (---) (from Fig. 2) were used as common reference values. For details of feeds, see p. $33 \mathrm{I}$ and Table I.

rate was somewhat greater and in the other somewhat less than that found after a whole-milk feed.

When whole milk was given to calf no. 2, but digesta from a collection made after a mineral-feed was returned to the duodenum, and when this procedure was reversed, the results suggested that, for these diets, control of abomasal emptying was exercised mainly by the composition of digesta entering the duodenum, rather than by that of material in the abomasum.

The results of the trials using calf no. 6 suggested that the control mechanism in sensitized calves which was responsible for differences in digesta flow between caseinfeeds and product B-feeds also operated as a result of differences in the composition of digesta entering the small intestine. 
Vol. 33

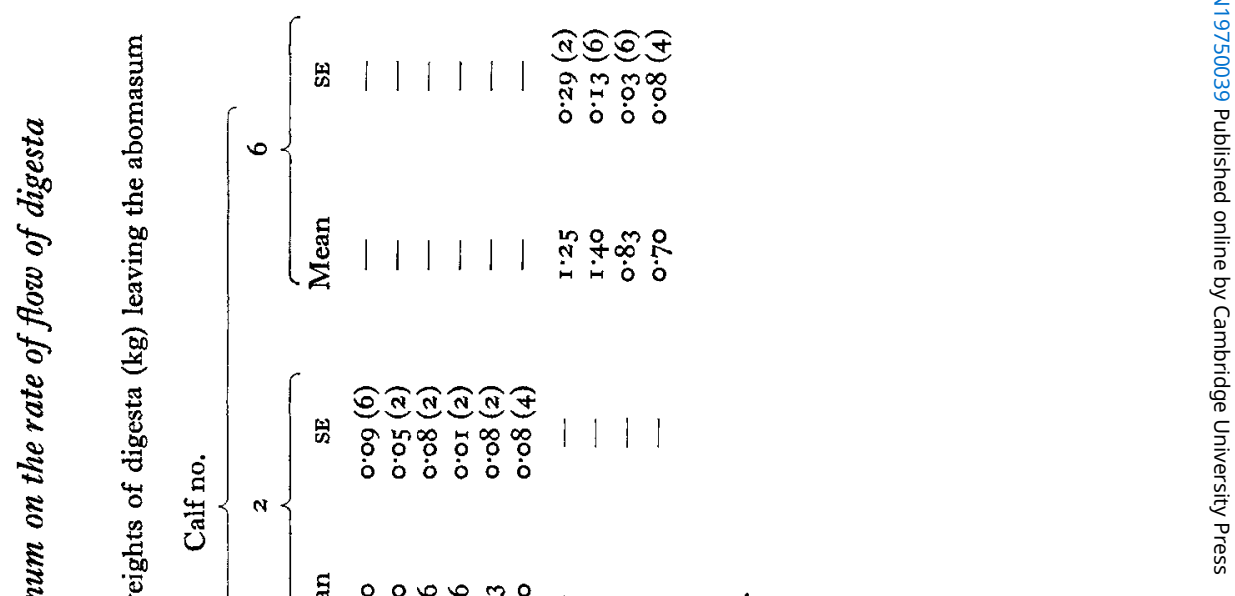
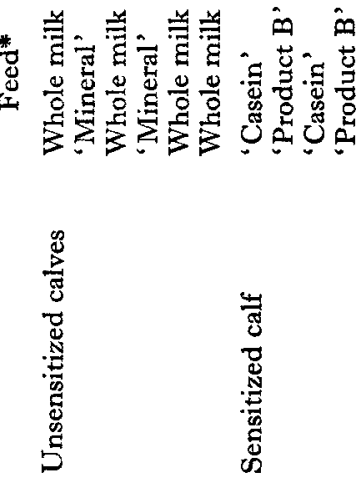


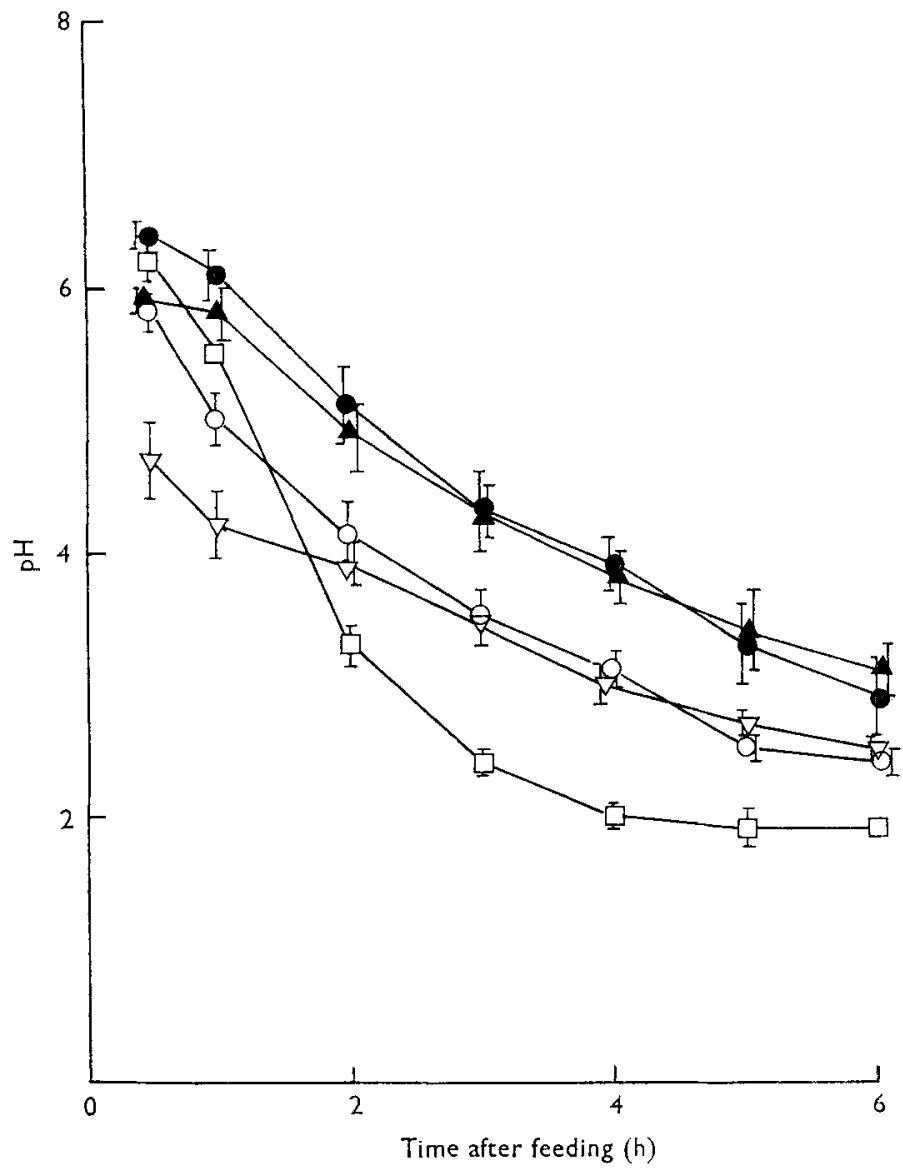

Fig. 7. $\mathrm{pH}$ of digesta samples collected from the proximal duodenum of calves at different times after receiving different feeds. Mean values, with their standard errors represented by vertical bars, are given for the whole-milk feed $(\nabla)$, casein-feed $(O)$, mineral-feed (containing no casein, fat or glucose) ( $\square$ ) and product B (heated soya-bean flour)-feed, unsensitized calf $(\boldsymbol{O})$, sensitized calf $(\boldsymbol{\Delta})$, given to eight, eleven, two, eight and eight individual calves respectively. Most of the individual calf values were themselves means of two to eight values. For details of feeds, see p. $33 \mathrm{I}$ and Table $\mathrm{r}$.

\section{pH of digesta leaving the abomasum}

Examples of $\mathrm{pH}$ values for digesta samples collected from a proximal duodenal cannula at different times after giving different feeds are given in Fig. 7. Samples collected $0.5 \mathrm{~h}$ after giving whole milk had lower $\mathrm{pH}$ values than corresponding samples obtained after giving the synthetic feeds (Fig. 7) or feeds prepared from products $\mathrm{A}, \mathrm{D}, \mathrm{E}$ and $\mathrm{F}$. For the latter feeds, $\mathrm{pH}$ values of samples collected $0.5 \mathrm{~h}$ after feeding were (mean and SE, no. of calves in parentheses): $6 \cdot 3 \pm 0 \cdot 3(4), 6 \cdot 0 \pm 0 \cdot \mathrm{I}$ (3), 6.2 $\pm 0 . \mathrm{I}(3)$ and $5 \cdot 4 \pm 0 \cdot 2(4)$ respectively. Values for samples collected $2 \mathrm{~h}$ after feeding whole-milk or casein-feeds were similar and markedly lower than that for the product B-feed (sensitized and unsensitized calves). Corresponding values for samples collected after giving feeds prepared from products A, D, E and F were (mean and 


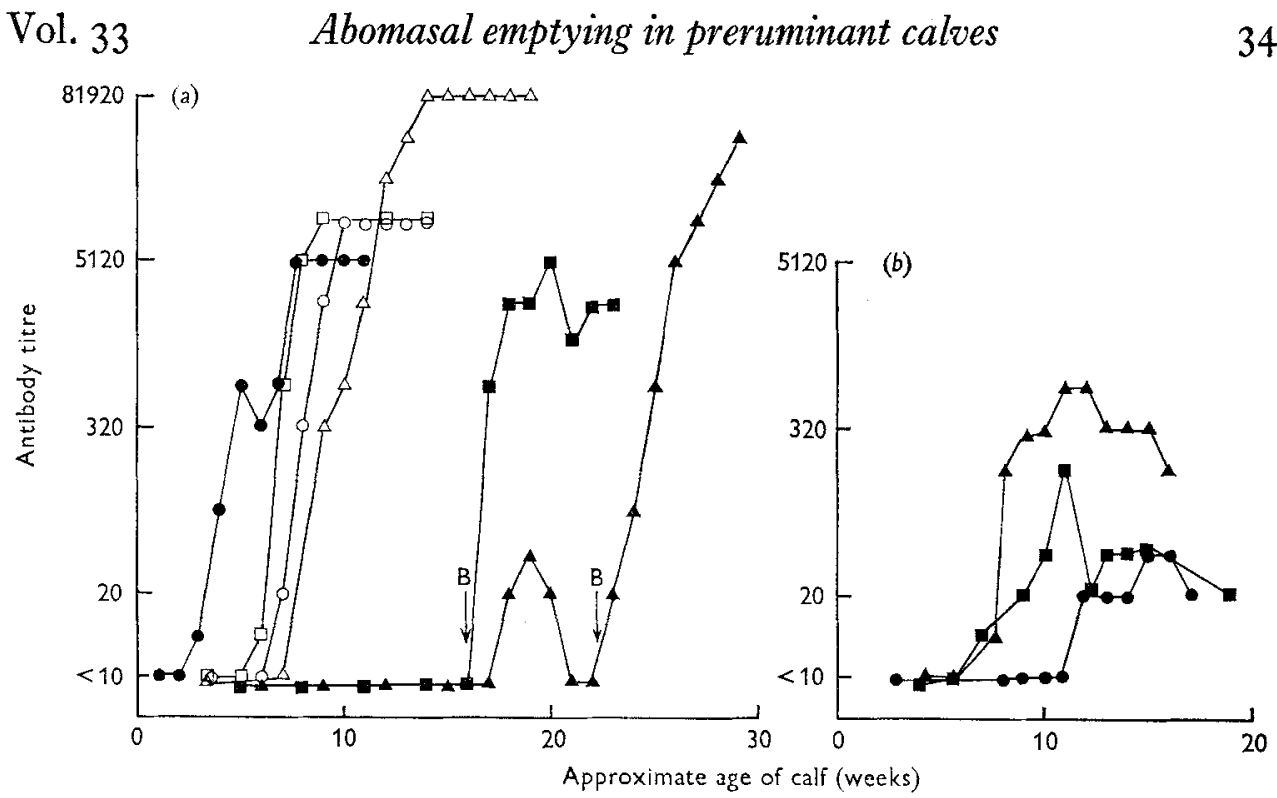

Fig. 8. Development of antibodies in the serum of individual calves given whole-milk diets supplemented with soya-bean products: $(a)$ product $B$ (heated soya-bean flour) from birth $(\odot)$, product $B$ from 5 weeks of age $(O, \triangle, \square)$ or product $D$ (soya-bean concentrate) from 5 weeks of age replaced by product $B$ from the ages indicated by arrows labelled ' $B$ ' $(\boldsymbol{A}, \mathbf{\square})$; (b) product $\mathbf{F}$ (soya-bean protein isolate (isoelectric)) from 5 weeks of age $(\mathbf{O}, \mathbf{A}, \boldsymbol{\square})$. For details of feeds, see p. 33 I and Table I.

$\mathrm{SE}$, no. of calves in parentheses): $4 \cdot 8 \pm 0.3(4), 4 \cdot 6 \pm 0.3(2), 4 \cdot 7 \pm 0.2(3)$ and $3 \cdot 6 \pm 0.1$ (4) respectively. The relationships between whole-milk, product $B$ - and casein-feeds persisted up to $6 \mathrm{~h}$ after feeding (Fig. 7) although differences by this time were not very marked. Samples obtained $6 \mathrm{~h}$ after giving feeds prepared from products $A, D$, $\mathrm{E}$ and $\mathrm{F}$ were also found to have similar $\mathrm{pH}$ values which were (mean and sE, no. of calves in parentheses): $3 \cdot 1 \pm 0.4(3), 2.4 \pm 0.2(2), 3.1 \pm 0.2$ (3) and $2.7 \pm 0.1$ (4) respectively. Results for the mineral-feed, also given in Fig. 7 , showed a rapid decrease in $\mathrm{pH}$ after feeding, and even after $6 \mathrm{~h}$ the value was somewhat lower than that for the other feeds.

\section{Properties of the nitrogenous compounds entering the duodenum}

There were appreciable differences between calves given feeds containing milk protein, in the proportions of the $\mathrm{N}$ compounds in digesta samples leaving the abomasum which were soluble in TCA. For samples collected $0.5 \mathrm{~h}$ after a cow's-milk feed these proportions were $0.39,0^{\circ} 13$ and 0.13 for calf nos. I, 2 and 3 respectively. Corresponding values for samples collected $6 \mathrm{~h}$ after the feed were $0 \cdot 26,0 \cdot 13$ and $0 \cdot$ I4. Values similar to these were obtained when the three calves were given caseinfeeds and when calf no. 3 was given product A- or product B-feeds. Higher proportions soluble in TCA $(0.26-0.58)$ were found for samples from calf no. 2 taken $0.5 \mathrm{~h} \cdot$ after a mineral-feed or product F-feed, probably because these samples consisted mainly of endogenous materials. For calf no. I, samples collected at I, 2 and 4 h after cow'smilk or casein-feeds were also examined; they showed values intermediate between the 0.5 and $6 \cdot 0 \mathrm{~h}$ values. 


\section{Production of serum antibodies in calves given soya-bean products}

Serum samples from two fistulated calves which had received seven to eight product B-feeds over periods of 6-7 weeks were found to contain antibodies to the soya-beanflour antigen and gave titres of 1280 and 5 120.

Further experiments were done using intact calves given diets in which about $30 \%$ of the protein was provided by the appropriate soya-bean product and the remainder was given as milk, for periods of several weeks. High serum antibody titres were obtained when the diet contained product B (Fig. 8), with much lower titres when product $F$ was used. For calves given diets containing product $D$ there was no appreciable antibody production. When, for the latter calves, product D was replaced by product $B$, there was a rapid development of serum antibodies.

When the calves with a high serum antibody titre were transferred to a milk diet containing no soya-bean product there was a slow decrease in the titre but, even after $3-4$ weeks, titres of $80-5$ I 20 were found.

\section{DISCUSSION}

It has been shown for man that stomach emptying is inhibited by a low $\mathrm{pH}$ and a high osmotic strength in digesta entering the duodenum (Hunt \& Knox, I969, 1971). Similar effects have been demonstrated for the calf (Tagari \& Roy, r969; Bell \& Razig, I973) and were presumably responsible for the inhibition of abomasal emptying found when an acidified solution containing $\mathrm{NaCl}$ and glucose (solution $\mathrm{A}$, Table 4 ) was infused into the calf duodenum. The results in Table 4 showed that the difference between flow rates from the abomasum found after giving a feed consisting of a mineral mixture alone, or after giving one containing also casein, fat and glucose, was mediated largely by an effect in the duodenum. Differences in the $\mathrm{pH}$ and osmotic strength of digesta undoubtedly played a part in establishing the extent of this difference, but the finding that the addition of either casein or fat to synthetic feeds results in a decrease in digesta flow, indicated that both these constituents, or products of their digestion, also influenced abomasal emptying. Triglycerides and products of their digestion are known to slow gastric emptying in man (Hunt \& Knox, I968).

If a calf was given only one or two feeds containing a soya-bean protein source rather than milk protein, the type of protein had little effect on the rate of abomasal emptying (Fig. 4). Colvin, Lowe \& Ramsey (r969) reported a similar finding for a calf given soya-bean flour for $5 \mathrm{~d}$. The marked inhibition of abomasal emptying which we found after giving further feeds of some soya-bean products, notably soyabean flours, were not related to any apparent change in the composition of the digesta. We found, like Colvin et al. ( 1969 ) that $\mathrm{pH}$ values were consistently higher for diets containing soya-bean flour than for those containing milk protein. The results therefore implied a change in the response characteristics of the calf. It is possible that the calf was sensitized by the first soya-bean product feeds and then reacted to further contact with them. Such a change and the finding that other changes in gut behaviour occurred only after a number of soya-bean product feeds was given, suggested that an 
allergic condition may have developed. The latter changes included decreased transit time through the small intestine, abnormal water and salt exchange in the small intestine and decreased $\mathrm{N}$ absorption up to the ileum (Smith et al. 1970; Smith \& Sissons, unpublished results). Gastrointestinal allergy to dietary proteins is believed to be responsible for a number of disorders in man although the mechanisms are generally ill-defined (Self, Herskovic, Czapek, Caplan, Schonberger \& Gryboski, 1969). A few cases of an apparent allergic reaction to soya-bean products given to infants have been reported (Cook, 1960; Ament \& Rubin, I972), although the results of most trials have suggested that milks prepared from properly heated soya-bean products are satisfactory for infant feeding (Vest et al. 1966; Sellars, Halpern, Johnson, Anderson, Saperstein \& Shannon, 1971).

For the calf, it seems likely that some soya-bean products contain a factor(s) which survives digestion in the abomasum and duodenum and which causes an allergic response to varying extents in different calves. The abomasal hold-up reported in the present paper probably does not have a dramatic effect on nutrient utilization, but it may be regarded as one manifestation of a wider disorder affecting the function of the small intestine.

Synthetic milks, in which soya-bean flour, heated to destroy trypsin inhibitor, provides the main part of the protein source, do not generally form satisfactory diets for preruminant calves. Calves given such diets usually have diarrhoea, very poor growth or weight loss and may eventually die (Stein et al. 1954; Gorrill \& Thomas, 1967; Colvin \& Ramsey, 1968; Nitsan, Volcani, Hasdai \& Gordin, r972) although in some experiments moderately good performance has been reported (Paruelle, Toullec, Frantzen \& Mathieu, 1972; Ramsey \& Witaszek, 1972). The allergenic factor suggested by our findings may be, at least in part, responsible for these effects. Colvin $\&$ Ramsey (I968) reported that treatment of a flour with acid or alkali may improve its nutritive value for calves. Treatments such as these may act by destroying the factor, and the varying severity of disorders reported by different workers in calves given diets containing high proportions of soya-bean flour may be due to unrecognized treatment differences affecting the factor. We have found (Smith \& Sissons, unpublished results) that flours prepared in nominally the same way by different manufacturers may have differing effects on the movement of digesta and water and salt exchange in the small intestine. Measurement of the inhibition of abomasal emptying and related effects may provide a means of monitoring the effects of different manufacturing conditions on the value of soya-bean products in calf feeding. Calves given feeds containing product $\mathrm{F}$ (which gave less abomasal hold-up than soya-bean flour, Table 3 ) as the sole protein source had fairly good $\mathrm{N}$ retention (Porter, 1969) and soya-bean concentrates prepared by ethanol extraction (product $D$ ), which do not lead to abomasal hold-up, were shown to support much better growth in calves than soya-bean flour (Gorrill \& Thomas, 1967; Nitsan, Volcani, Gordin \& Hasdai, 197I). Attempts to determine whether the latter improvement was due to destruction or extraction of a deleterious factor by the ethanol treatment (by comparing the effects of giving feeds containing products $\mathrm{C}$ and $\mathrm{D}$ ) gave results which suggested the former possibility, but the results of other studies on the effect of ethanolic extracts of soya-bean meal 
on digesta flow (Smith \& Sissons, unpublished results) suggest that both processes may play a part. The conditions of the ethanol treatment, e.g. time, temperature, relative amounts of ethanol and water, may affect the extent of removal of the deleterious factor, but no information is yet available on such variations.

The extent to which gastrointestinal allergic responses may be related to levels of antibodies in the blood is uncertain. Gryboski (I967) was unable to detect any circulating antibodies in children who had an allergy to milk protein but wheat gluteninduced enteropathy was associated with the presence of circulating antibodies to a factor in the diet (Taylor, Thomson, Truelove \& Wright, r96r). Our results suggested that there was a possible relationship between the severity of digestive disorders produced in calves by different soya-bean products and the level of antibodies that the products engendered. Thus, product B produced high levels of circulating antibodies and severe disturbances in digesta flow, but product $F$ produced low levels of circulating antibodies and moderate disturbance of digesta flow and product $\mathrm{D}$ produced no antibodies or disturbances. Limited results (p. 34I) suggested that product $G$ produced severe disturbance of digesta flow and this may have been related to the finding of van Leeuwen et al. (I969) that this product produced high levels of circulating antibodies. Further evidence is needed, however, before firm conclusions can be made.

It is of interest that in both the present experiments and in those of van Leeuwen et al. (rg69) very high antibody titres $(>40960)$ were sometimes found. These values were considerably higher, for example, than those found when calves were sensitized to ovalbumin by intravenous injection (Aitken, Sanford \& Zarkower, I974). The reason for this is unknown but very high titres $(>20000)$ were also found in human subjects responding to dietary wheat gluten (Taylor et al. I96I).

Our results support the findings of other workers (Mylrea, 1966 b; Toullec \& Mathieu, r973) that, as a result of the clotting of whole milk in the calf abomasum, $\mathrm{N}$ leaves this organ after a whole-milk feed at a fairly constant rate over a period of many hours. This probably allows efficient operation of the digestive processes, and failure of a feed to clot might upset these processes. The expected effect of a failure to clot would be a relatively rapid flow of $\mathrm{N}$ soon after feeding. This characteristic was shown to a limited extent for the casein synthetic feed and the soya-bean-flourfeeds, although both showed some hold-up of nitrogenous compounds in the abomasum in comparison to water-soluble constituents. The greatest disturbance of $\mathrm{N}$ flow was for product F-feeds, but this was produced by a temporary, selective hold-up of nitrogenous compounds for an unknown reason, followed by their rapid release. The idea that disturbances of $\mathrm{N}$ flow may lead to disorders is supported by the findings of Tagari \& Roy (1969) that the poor performance of calves given a milk prepared from overheated, spray-dried, skim-milk powder was associated with a loss of clotting ability of the diet. On the other hand Toullec, Thivend \& Mathieu (I97I) found no loss of performance in calves given a non-clotting diet. It is not certain, therefore, whether or not the variations in the selective hold-up of $\mathrm{N}$ compounds in the abomasum for our different diets had any deleterious effects on $\mathrm{N}$ nutrition. 
The authors thank Dr A. T. Cowie, Dr H. Buttle and Mr S. Watson for carrying out all surgical operations, Mr W. B. Hill and Mrs S. J. Askew for assistance with the animal experimentation and a succession of sandwich-course students, notably from the University of Bradford, for invaluable general help.

\section{REFERENCES}

Aitken, M. M., Sanford, J. \& Zarkower, A. (1974). Res. vet. Sci. 16, 199.

Ament, M. E. \& Rubin, C. E. (1972). Gastroenterology 62, 227.

American Oil Chemists' Society (1965). Official and Tentative Methods 3rd ed. Tentative method

Ba I I-65. Chicago: American Oil Chemists' Society.

Ash, R. W. (1 962). Anim. Prod. 4, 309.

Ash, R. W. (1964). F. Physiol., Lond. 172, 425.

Bell, F. R. \& Razig, S. A. D. (1973). F. Physiol., Lond. 228, 499.

Boyden, S. V. (195x). 7. exp. Med. 93, 107.

Coalson, J. A., Jones, E. E. \& Lecce, J. G. (1972). J. Anim. Sci. 35, 214.

Colvin, B. M. \& Ramsey, H. A. (1968). F. Dairy Sci. 5I, 898.

Colvin, B. M., Lowe, R. A. \& Ramsey, H. A. (1969). F. Dairy Sci. 52, 687.

Cook, C. D. (1960). New Engl.F. Med. 263, ro76.

Coombe, N. B. (1972). Carbohydrate digestion and absorption in the preruminant calf. PhD Thesis, University of Reading.

Coombe, N. B. \& Smith, R. H. (1973). Br. F. Nutr. 30, 33 I.

Fleck, A. \& Munro, H. N. (1965). Clinica chim. Acta I1, 2.

Frazer, A. C., Fletcher, R. F., Ross, C. A. C., Shaw, B., Sammons, H. G. \& Schneider, R. (1959). Lancet ii, 252.

Gorrill, A. D. L. \& Thomas, J. W. (1967). F. Nutr. 92, 2 1 5.

Gryboski, J. D. (1967). Pediatrics, Springfield 40, 354.

Hunt, J. N. \& Knox, M. T. (1968). F. Physiol., Lond. 194, 327.

Hunt, J. N. \& Knox, M. T. (1969). F. Physiol., Lond. 201, I6r.

Hunt, J. N. \& Knox, M. T. (1971). In Gastrointestinal Motility p. 46 [L. Demling and R. Ottenjaun, editors.]. New York: Academic Press.

Kakade, M. L., Rackis, J. J., McGhee, J. E. \& Puski, G. (1974). Cereal Chem. 51, 376.

Mylrea, P. J. (1966a). Res. vet. Sci. 7, 333 .

Mylrea, P. J. (1966b). Res. vet. Sci. 7, 394.

Nitsan, Z., Volcani, R., Gordin, S. \& Hasdai, A. (197r). F. Dairy Sci. 54, 1294.

Nitsan, Z., Volcani, R., Hasdai, A. \& Gordin, S. (r972). F. Dairy Sci. 55, 81 r.

Paruelle, J.-L., Toullec, R., Frantzen, J.-F. \& Mathieu, C.-M. (r972). Annls Zootech. 21, 319.

Phillipson, A. T. (1952). F. Physiol., Lond. 116, 84.

Porter, J. W. G. (1 969). Proc. Nutr. Soc. 28, I I 5.

Ramsey, H. A. \& Witaszek, P. (1972). F. Dairy Sci. 55, 705.

Roy, J. H. B., Shillam, K. W. G., Hawkins, G. M. \& Lang, J. M. (1958). Br. F. Nutr. 12, 123.

Self, T. W., Herskovic, T., Czapek, E., Caplan, D., Schonberger, T. \& Gryboski, J. D. (I969). F. Am. med. Ass. 207, 2393.

Sellars, W. A., Halpern, S. R., Johnson, R. B., Anderson, D. W., Saperstein, S. \& Shannon, B. S. (197I). Ann. Allergy 29, I26.

Siewert, K. L. \& Otterby, D. E. (1968). F. Dairy Sci. 51, I305.

Smith, R. H. (1958). Nature, Lond. $\mathbf{1 8 2}, 260$.

Smith, R. H. (1962). Biochem. F. 83, I5 I.

Smith, R. H., Hill, W. B. \& Sissons, J. W. (1970). Proc. Nutr. Soc. 29, 6A.

Smith, R. H. \& Wynn, C. (197r). Proc. Nutr. Soc. 30, 75 A.

Stein, J. F., Knodt, C. B. \& Ross, E. B. (1954). F. Dairy Sci. 37, 373.

Tagari, H. \& Roy, J. H. B. (r969). Br. F. Nutr. 23, 763.

Taylor, K. B., Thomson, D. L., Truelove, S. C. \& Wright, R. (196r). Br. med. F. ii, I727.

Technicon Instruments Ltd (1967). Technicon Methodology Sheet N-3b. Basingstoke: Technicon Instruments Ltd.

Toullec, R. \& Mathieu, C.-M. (1973). Annls Rech. vet. 4, I3.

Toullec, R., Thivend, P. \& Mathieu, C.-M. (I971). Annls Biol. anim. Biochim. Biophys. 1r, 435.

van Adrichem, P. W. M. \& Frens, A. M. (1965). Tijdschr. Diergeneesk. 90, 525.

van Leeuwen, J. M., Weide, H. J. \& Braas, C. C. (1969). Versl. landbouwk. Onderz. Ned. no. 732.

Vest, M., Olafson, A. \& Schenker, P. (1966). Schweiz. med. Wschr. 96, 762. 